\author{
Ali Murat Ceyhan, \\ Gonca Meriç, \\ ijlal Erturan
}

\author{
Nadir Görülen Bir Fotodermatoz: \\ Hidroa Vaksiniforme \\ A Rarely Seen Photodermatosis: \\ Hydroa Vacciniforme
}

\section{Sayın Editör,}

Hidroa vaksiniforme (HV), etyolojisi tam olarak bilinmeyen, sıklıkla çocukluk yaş grubunda ortaya çıkan ve oldukça nadir görülen kronik bir fotodermatozdur. Illk kez 1862 yılında Bazin tarafından tanımlanmıştır. Güneş gören bölgelerde tekrarlayan papüloveziküler lezyonlar ve bu lezyonlar sonucu gelişen varioliform sikatrisler ile karakterizedir $(1,2)$.

Dokuz yaşında kız hasta, polikliniğimize yüz, kulak kepçesi ve kollarda içi su dolu kabarcıklar ve kabuklu yara yakınması ile başvurdu. Yakınmaları ilk kez 4 yaşında başlayan hastanın şikayetlerinin özellikle yaz aylarında belirgin olarak arttığı öğrenildi. Güneşe çıktıktan sonra birkaç saat içinde yüz ve kollarında içi su dolu minik kabarcıklar geliştiğini belirten hasta, daha sonra bunların kabuklanıp deriden çökük iz bırakarak iyileştiğini ifade etti. Hafif şiddette kaşıntı ve yanma hissi tarifleyen hastanın aile öyküsü ve fotosensitizan ilaç kullanım hikayesi yok idi. Dermatolojik muayenede yüzde burun kanadında, kol ekstansör yüzlerinde ve kulak kepçesinde yer yer hemorajik krutla kaplı papüloveziküler lezyonlar ve varioliform skarlar izlendi (Resim 1,3). Saç dökülmesi, tırnak anomalisi, hipertrikoz ve milyum saptanmadı

Hemogram, kan biyokimyası ve tam idrar tetkikini içeren rutin Laboratuvar değerleri normal sınırlarda idi. ANA, anti DNA düzeyleri ve Epstein Barr virus (EBV) ile ilgili serolojik testlerinden antiviral kapsid antijen (VCA) IgG, IgM ve anti-EBV nükleer antijen (EBNA) Ig M negatif idi. İdrar renginde koyulaşma tariflemeyen hastanın idrar üroporfirin 1, III ve serum koproporfirin düzeyleri de negatif olarak saptandı. Klinik bulgular ve öyküye dayanarak olgumuza HV tanısı konuldu ve tedavi olarak güneşten koruyucu krem ve hafif potenste topikal kortikosteroid önerildi.

HV ilkbahar ve yaz aylarında güneşle temas eden deri bölgelerinde görülmektedir. Genellikle çocukluk döneminde başlayan ve ataklar halinde devam eden yakınmalar adelösan döneminden sonra kendiliğinden gerileme eğilimi göstermektedir. Lezyonlar güneş temasından sonra ortalama $30 \mathrm{dk}-2$ saat içerisinde hafif yanma ve kaşıntı ile eritemli döküntüler şeklinde başlar ve kısa süre içinde papüloveziküler karakter kazanır. Hemorajik ve göbekli olma eğiliminde olan veziküller birkaç gün içinde kurutlanır ve birkaç hafta içinde de merkezi nekroze olup hipopigmente ve deprese suçiçeği benzeri sikatris bırakarak iyileşir. Olgumuza benzer şekilde burun sırtı, yanak, kulak, el ve kolların ekstansör yüzlerinin simetrik tutulumu oldukça tipiktir $(1,2)$.

HV etyopatogenezi tam olarak açıklığa kavuşmamakla birlikte UVA'ya karşı gelişen geç tip aşırı duyarlılık reaksiyonu olduğu iddia edilmektedir. Hastaların bir kısmında UVA'ya karşı düşük minimal eritem dozları saptanmıştır. Latent Epistain Barr virüs infeksiyonları da patogenezde suçlanmış ve HV'nin EBV ile ilişkili bir lenfoproliferatif bir hastalık olduğu bildirilmiştir (2-5).

Tanı klinik olarak konulmaktadır. Histopatolojik incelemede intraepidermal vezikül, hiperkeratoz ve akantozun yanı sıra diğer fotodermatozlardan farklı olarak nekroz daha belirgindir. Eritropoetik protoporfirya, porfirya kutane tarda, polimorf ışık erüpsiyonu, büllöz lupus eritematozus, hidroa estivale ve kseroderma pigmentozum ayırıcı tanıda düşünülmesi gereken hastalıklardır $(1,2)$. Olgumuzda serum ve idrar porfirin düzeylerinin negatif olması ile, hipertrikoz, milyum ve sikatrisyel alopesinin olmaması, ANA, Anti DNA düzeyinin negatif 


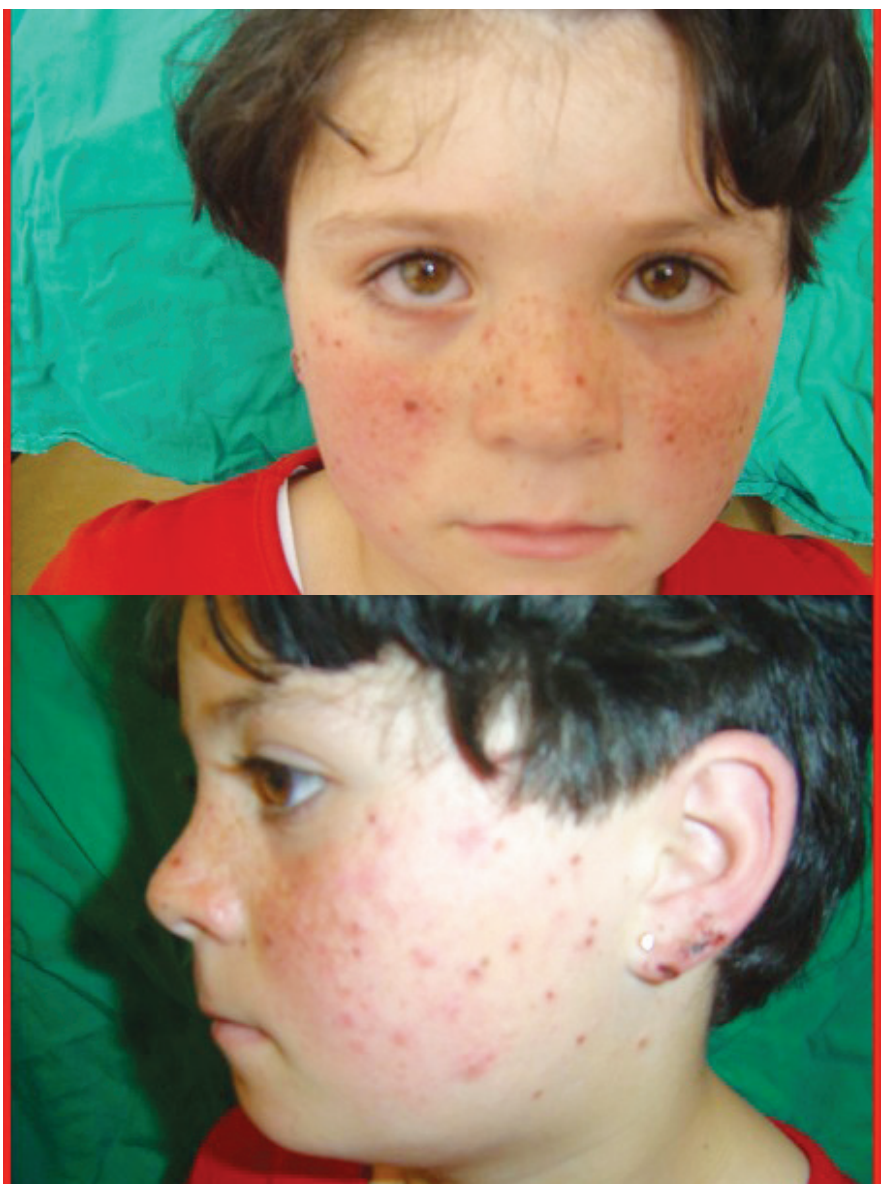

Resim 1-2. Yüz bölgesinde yaygın yerleşimli ve yer yer ortası nekrotik kurutlu papüloveziküller

olması, lezyonların varioliform skarla iyileşmesi ve kutanöz malignitelerin ve poikilodermanın eşlik etmemesi nedeni ile bu ayırıcı tanılar ekarte edildi.

HV'nin güneşten sakınma ve güneşten koruyucular dışında etkin bir tedavisi yoktur. UVA koruyucu güneş gözlüklerinin kullanılması da gelişebilecek korneal lezyonların oluşumunu engelleyebilir. PUVA veya dar band UVB ile profilaktik fototerapi yararlı olabilir. Beta karoten, antimalaryaller, azatiyopürin, siklosporin sistemik tedavi seçenekleri arasında yer almaktadır. Ancak hastalığın yaş grubu nedeni ile bu tedavilerden kaçınılması da önerilmektedir (4).

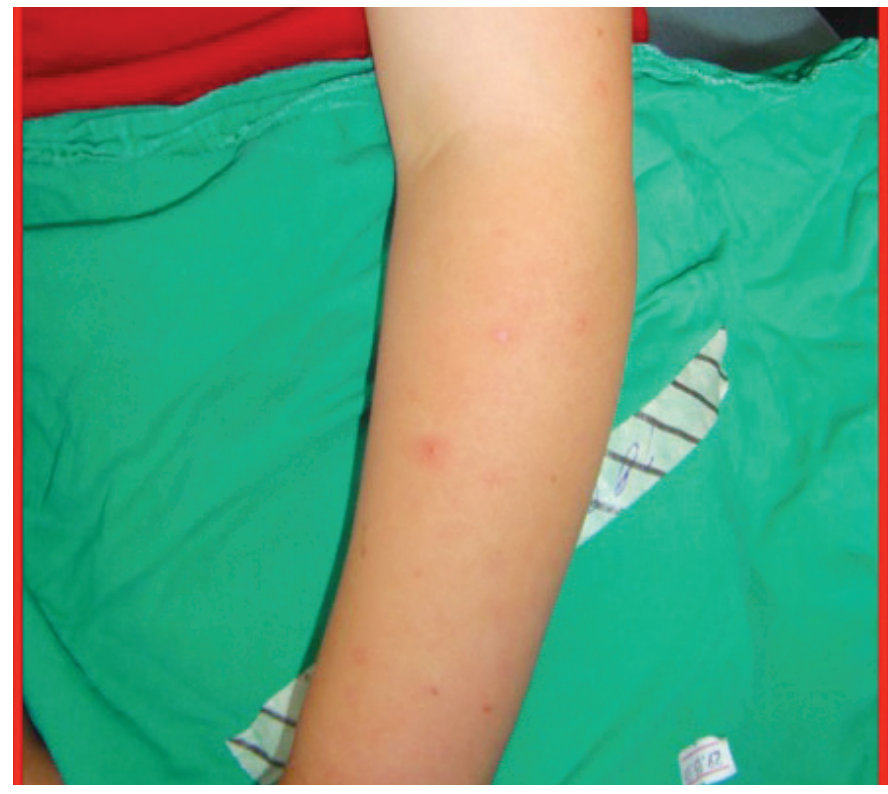

\section{Resim 3. Sol kol ve önkol bölgesinde yer alan papüloveziküller}

Olgumuz oldukça nadir görülen bir fotodermatoz olan HV'nin erken tanısı ve güneşten koruyucu önlemler ile ileride yüzde gelişebilecek ve ciddi kozmetik sorun oluşturacak kalıcı skatris ve sekellerin önüne geçilebileceğini vurgulamak amacı ile sunulmuştur.

\section{Kaynaklar}

1. İnalöz S. İdiyopatik fotodermatozlar. In: Tüzün $Y$, Kotoğyan A, Serdaroğlu S, Çokuğraş S, Tüzün B, Mat C, editors. Pediyatrik Dermatoloji. 1 st ed. İstanbul: Nobel Kitabevleri; 2005. p.270-3.

2. Oksay T. Hidroa vaksiniforme. In: Tüzün Y, Serdaroğlu S, Erdem C, Özpoyraz M, Önder M, Öztürkcan S. Dermatolojide Tedavi. 1st ed. İstanbul: Nobel Kitabevleri; 2010. p.335-7.

3. Park HY, Park JH, Lee KT, et al. A case of hydroa vacciniforme. Ann Dermatol 2010;22:312-5.

4. Xie JL, Chen GY, Jin Y, et al. Hydroa vacciniforme present for 48 years with cytotoxic CD4+ T-cell infiltration and Epstein-Barr virus infection. $\mathrm{Br} J$ Dermatol 2012;166:449-51.

5. Cohen Jl, Kimura H, Nakamura S, et al. Epstein-Barr virus-associated lymphoproliferative disease in non-immunocompromised hosts: a status report and summary of an international meeting, 8-9 September 2008. Ann Oncol 2009;20:1472-82. 